\title{
THE CIVIL SOCIETY AND THE REGULATION OF THE EXTRACTIVE INDUSTRY IN NIGERIA
}

\author{
Rhuks Ako* \\ Eghosa O. Ekhator ${ }^{* *}$
}

\begin{abstract}
This article focuses on the role of civil society organisations (CSOs) in impacting on trends and developments in the extractive industry in Nigeria. For example, CSOs take on the government to promote accountability and probity in the management of the sector that is beset by ineffectual regulation; alleged collusion with multinational corporations having as consequences environmental degradation and human rights abuses; and, ineffective judicial processes, among other things. On the other hand, CSOs are increasingly beginning to play prominent roles in collaborations with extractive corporations in the initiation and management of development programmes. In a nutshell, this paper aims to engage with both theoretical (based on the Hood et al conceptualisation of a regulatory regime, which encompasses information gathering, standard setting and behaviour modification activities) and practical frameworks (such as litigation, collaboration and pressure by CSOs) that explain the evolution of CSOs and their "regulatory" roles in Nigeria's extractive industry. Civil society and civil society organisation are used interchangeably.
\end{abstract}

Keywords: Nigeria, CSOs, extractive industry, regulatory framework.

doi: http://dx.doi.org/10.4314/jsdlp.v6i2.9

\section{INTRODUCTION}

CSOs play active roles in the extractive industry in Nigeria. The Niger Delta has been a centre of protests due to the activities of oil multinational

* Senior Fellow, Institute for Oil, Gas, Energy, Environment and Sustainable Development, Afe Babalola University, Nigeria. Email: rako@ogeesinstitute.edu.ng

** University of Hull Law School, UK. Corresponding author: Email: eghosaekhator@gmail.com 
corporations (OMNCs) and the inactions of governmental agencies. ${ }^{1} \mathrm{CSO}$ and many communities have been at the forefront of promoting the interests of the people of the Niger Delta. ${ }^{2}$ Recently, the activities of CSOs have impacted on the regulatory framework in the extractive sector in Nigeria. This paper will analyse the impacts of CSOs via the framework developed by Hood et $a .^{3}$

This article is divided into five sections. The first section is the introduction. The second focuses on the conceptual framework of CSOs. Here, the definition and the quest for an African conceptualisation of CSO will be in focus. The third section will highlight the Hood et al framework. The fourth section analyses specific examples of CSO influence on the Nigeria's extractive industry. The fifth section, which is the concluding part of the paper, contends that, in Nigeria, CSOs perform "quasi-regulatory" functions via their activities in the oil and gas sector. For example, CSOs can challenge MNCs and the government by boycotts, public campaigns and other forms of pressure.

\section{CONCEPTUAL FRAMEWORK}

The literature is replete with numerous definitions of civil society, mainly due to the "varied and loose manner in which civil society is used in academic and popular discourses." ${ }^{4}$ As Allen has noted in the above regards, the notion of civil society has become "diffuse, hard to define, empirically imprecise and ideologically laden." ${ }^{5}$ One way of identifying civil society is by identifying who may be included in this classification ${ }^{6}$ or excluding those that cannot be incorporated. It is incontrovertible that while state and profit-oriented organisations are excluded, non-governmental organisations (NGOs), trusts,

1 Victor Ojakorotu, "The Dynamics of Oil and Social Movements in the Niger Delta of Nigeria" (2006) 3 (1) Journal of Multidisciplinary International Studies 1-14, 1.

2 Eghosa Osaghae, "Social Movements and Rights Claims: The Case of Action Groups in the Niger Delta of Nigeria" (2008) 19 (2) Voluntas 189.

3 Christopher Hood et al, The Government of Risk (Oxford University Press 2001).

4 Adedayo Adekson, The Civil Society's Problematique: Deconstructing Civility and Southern Nigeria's Ethnic Radicalisation (Routledge 2004) 35.

5 Chris Allen, "Who Needs a Civil Society?" (1997) 24 (73) Review of African Political Economy 329.

6 Barbara Gemmill \& Abimbola Bamidele-Izu, "The Role of NGOs and Civil Society in Global Environmental Governance" in Daniel Esty \& Maria Ivanova (eds.) (2002) Global Environmental Governance: Options \& Opportunities (Yale School of Forestry and Environmental Studies 2002). 
charities, foundations, advocacy groups, national and international non-state organisations are included. ${ }^{7}$ It is for this reason that civil society is often referred to as the third sector.

In Africa, the Economic, Social and Cultural Council (ECOSOCC), which is the vehicle for building a strong partnership between governments and all segments of the African civil society ${ }^{8}$ has identified the groups that fit into the nomenclature of "civil society" on the continent. According to ECOSOCC,

CSOs include but are not limited to the following: (a) Social groups such as those representing women, children, the youth, the elderly and people with disability and special needs; (b) Professional groups such as associations of artists, engineers, health practitioners, social workers, media, teachers, sport associations, legal professionals, social scientists, academia, business organisations, national chambers of commerce, workers, employers, industry and agriculture as well as other private sector interest groups; (c) Non-governmental organisations (NGOs), community-based organisations (CBOs) and voluntary organisations; d) Cultural organisations; and (e) social and professional groups in the African Diaspora in accordance with the definition approved by the Executive Council. ${ }^{9}$

In essence, the civil society in Africa encapsulates formal and informal groups or organisations such as religious groups, local communities and market women. ${ }^{10}$

Posner's definition and theorisation of civil society highlights the critical contribution that civil society makes to governance. While defining civil society as the "the reservoir of formal and informal organisations outside of state control", ${ }^{11}$ Posner identifies advocacy and substitution as the two mechanisms that academic literature uses to buttress the relationship between good

7 Bridget Hutter \& Joan O'Mahony, "Business Regulation: Reviewing the Regulatory Potential of Civil Society Organisations" (ESRC Discussion Paper 2004).

8 Articles 5 and 22 of the African Union's Constitutive Act.

9 Available at: < http://au.int/en/organs/ecosocc > accessed 20 December 2015.

10 Thelma Ekiyor, The Role of Civil Society in Conflict Prevention: West African experiences (2008) United Nations Institute for Disarmament Research (UNIDIR), Disarmament Forum: The complex dynamics of small arms in West Africa, Number 4, 27.

11 Daniel Posner, "Civil Society and Reconstruction of Failed States" in Rotberg, R.I. (ed.) When States Fail: Causes and Consequences (Princeton University Press 2004) 237. 
government conduct and civil society. Under the advocacy model, public services are provided because civil society monitors the conduct of government officials and confront them (by lobbying or putting pressure for instance) when they fail to provide public goods or services. ${ }^{12}$ In the substitution model, civil society engages more in the provision of services or contributes to social welfare by "furnishing the organisational structure and human and financial resources to provide the order and public services that citizens' desire." ${ }^{13}$ The substitution model is highly prevalent in the Niger Delta of Nigeria and other parts of the country. In Mushin, a suburb of Lagos State, for example, the Oodua People's Congress (OPC), a local vigilante/socio-cultural group, provides security instead of the conventional police. ${ }^{14}$

Two categories of civil groups are discussed here for their particular contributions to the development of Nigeria's oil-rich Delta region via advocacy and substitution. These are community or ethnic-based groups and the civil and environmental rights groups. Community or ethnic-based groups are associations of self-organised, self-governing kinsmen with objectives geared towards the development of the community or ethnic group. These objectives may be the provision of social services such as infrastructure town halls, school buildings, for example, or, provision of services viz. medical and educational enlightenment. ${ }^{15}$ Movement for the Survival of the Ogoni People (MOSOP), a classic example of a CBO (community or ethnic based organisation), succeeded in sensitising the Ogonis on issues relating to the oil industry, their environment and human rights as well providing other communities and ethnic groups with a template to replicate their (MOSOP) activities. The civil and environmental rights group includes organisations that have as their objective the promotion of civil and environmental rights such as Friends of the Earth, Amnesty International amongst others. This subset of CSOs includes local and foreign groups that not only form alliances with themselves but also with CBOs to achieve their objectives. ${ }^{16}$

In essence, this section contends that CSOs are perhaps better identified than construed by an absolute definition. Nonetheless, a working definition

12 ibid.

13 ibid 239.

14 Yinka Omorogbe, "Alternative Regulation in Africa" in B. Barton et al, eds. Regulating Energy and Natural Resources (Oxford University Press 2006).

15 Shittu Akinola, "Coping with Social Deprivation through Self-Governing Institutions in oil Communities" (2008) 55 (1) Africa Today, p. 89.

16 Evaristus Oshionebo, Regulating Transnational Corporations in Domestic and International Regimes: An African Case Study (University of Toronto Press 2009) 98. 
must be proffered to provide context to the discussion. With this in mind, CSOs, in this paper, refer to the "the formation of associational life ${ }^{17}$ of citizens characterised by common interests and identities, civil and public purposes, and collective and autonomous actions." 18

\section{OVERVIEW OF FRAMEWORK ON RISK REGULATORY REGIME}

This section will briefly highlight the Hood et al framework. Hood et al posited that any analysis of a regulatory regime brings to the fore, two distinct connotations or dimensions. ${ }^{19}$ First is that any (risk) regulatory regime entails "the three components that form the basis of any control system - that is, ways of gathering, ways of setting standards, goals, or targets, and ways of changing behaviour to meet the standards or targets." ${ }^{20}$ Simply put, the first dimension involves information gathering, standard setting and behaviour modification. The second dimension of a risk regulatory regime is the distinction or difference between regulatory regime or "context" and regime "content". ${ }^{21}$ A regime context is the background wherein the regulatory regime is localised, entailing the preponderance of risk, different manifestation and how such risks are being addressed, the extent of public attitude towards risk and how the different actors are affected by the hazard inherent in such risk regimes..$^{22}$ On the other hand, the regime content is said to be the interplay or policy setting of the state and other organisations or institutions involved in regulating or addressing the risks and attitudes or bias of the regulators. ${ }^{23}$

The first dimension of the risk regulatory regime highlighted above is analogous to the regulatory process. For example, in a command and control based regulatory framework, the state or regulatory agencies partake in the

17 In Africa, the term "Associational Life" includes civic organisations (such as NGOs) whose ideals are maintaining an un-biased oversight of government activities and national conferences, which are quite unique to Africa. Michael Bratton, Civil Society and Political Transition in Africa (IDR Reports Vol. 11 No. 6, 1994) 2.

18 Augustine Ikelegbe, "Civil Society, Oil and Conflict in the Niger Delta Region of Nigeria: Ramifications of Civil Society for a Regional Resource Struggle" (2001) 39 (3) Journal of Modern African Studies 437, 439.

19 Hood et al (n 3) 21.

20 ibid.

21 ibid.

22 ibid.

23 ibid. 
regulatory process by engaging in information gathering, standard setting and behaviour modification activities. However, it has been argued that the CSOs can also partake or contribute to the aforementioned three components of the control components of risk regime as enunciated by Hood et al. ${ }^{24}$ The contention of this paper is that CSOs have engaged or participated in regulatory regime in Nigeria's extractive sector via the three control components of the risk regulatory regimes as enunciated by Hood et al.

The next section of the paper will analyse specific examples of CSO influence on Nigeria's extractive industry. This section will highlight the role that civil societies play in shaping the legal framework that regulates the extractive industry.

\section{THE ROLE OF CSOS IN THE REGULATION OF THE EXTRACTIVE INDUSTRY IN NIGERIA}

A regulatory regime can be defined as the laws, regulations and policies guiding an industry or sector. Nigeria operates a command and control type of regulation in the oil and gas sector. ${ }^{25}$ The traditional command and control regulatory process is analogous to state legislation. ${ }^{26}$ However, the command and control or state-centric regulation is beset by many ills. ${ }^{27}$ Arguably, the void created in the extractive sector by the non-performance of government regulatory bodies and the non-implementa-tion of existing legal enactments is gradually being filled by CSOs. CSOs in Nigeria have proved by their antecedents that they have major roles to play. This was especially evident during the Ogoni crisis where the Movement for the Survival of the Ogoni People (MOSOP and other CSOs) played prominent roles in bringing the alleged atrocities of Shell and its Nigerian government cohorts to the attention of the world. ${ }^{28}$

24 Hutter and O' Mahony (n 7) 5.

25 Oshionebo (n 16).

26 Tetty Havinga, "Conceptualising Regulatory Arrangements: complex networks of actors and regulatory roles" (2012) Nijmegen Sociology of Law Working Paper Series, 13.

27 Eghosa Ekhator, "The Roles of Non-State Actors in the Regulation of Multinational Corporations in the Oil and Gas Industry in Nigeria" (PhD Thesis, University of Hull 2014).

28 Eghosa Ekhator, "Regulating the Activities of Oil Multinationals in Nigeria: A Case for Self-regulation?" 60 (1) (2016) Journal of African Law 1. 
The next section will focus on the roles of CSOs in the regulatory regime via the prisms of information gathering, standard setting and behaviour modification activities.

\subsection{Information Gathering}

Arguably, CSOs in Nigeria play vital roles in information gathering in Nigeria's extractive sector. Williams et al states that information gathering entails the "provision for information-gathering, producing knowledge and enabling actors to judge levels of risks." ${ }^{29}$ CSOs engage in information gathering activities in the regulation process by reporting on the industry, acting as watch dogs over government activities and engaging in auditing or monitoring of government activities, among other activities. ${ }^{30}$ There is a plethora of publications commissioned by CSOs on Nigeria's oil industry (including inhouse reports, discussion papers, briefings, books, newspaper articles, etc.) that provide valuable insights into an erstwhile opaque industry tainted with corruption. ${ }^{31}$

A good example is the 2012 "subsidy saga" wherein the federal government announced the removal of subsidies on petroleum products thereby driving petrol prices up from N65 to N141 per litre. This led to the increase in the prices of goods and services including basic necessities such as food, rent, transport and electricity. The federal government made the announcement on 1 January 2012 even when consultations with CSOs on the issue were ongoing. ${ }^{32}$

There are two important things to glean from the above. First is that the government deemed it pertinent to engage with civil society thereby highlighting recognition of the role that they play in information gathering and dissemination. Here, the protests were mainly organised online and via the use of social media and mobile phones. Also, protests took place within

29 Steve Williams, "Civil regulation and HRM: The Impact of Civil Society Organisations on the Policies and Practices of employers" (2011) 21(1) Human Resource Management Journal 52.

30 Hutter \& O' Mahony (n 7).

31 Environmental Rights Action and The Climate Justice Programme, "Gas Flaring in Nigeria: A Human Rights, Environmental and Economic Monstrosity", (June 2005) <www.foe.co.uk/resource/reports/gas_flaring_nigeria.pdf> accessed 20 December 2015.

32 Ogala Emmanuel and Ben Ezeamalu, "Occupy Nigeria: One Year later, the Gains, the Losses" Premium Times (12 January 2012) < http://premiumtimesng.com/ news/114890-occupynigeria-one-year-later-the-gains-the-losses.html\#/jobs > accessed 20 December 2015. 
and outside Nigerian borders. Second is that it was also an acknowledgment that CSOs wield influence over the populace. These two observations came to play following the "premature" announcement.

A coalition of CSOs and labour unions under a loose umbrella of "Occupy Nigeria" staged protests within and outside the country, utilising both traditional and contemporary media sources based on two broad premises. ${ }^{33}$ One was that the subsidy removal would bring hardship on the populace and should be reversed. The other and more pertinent to the discussion here was the reasoning that Nigeria's oil industry should become more transparent and accountable to Nigerians. The central question in this regard was the perceived institutional corruption that pervaded the said "subsidy payments" and the general management of oil revenues. ${ }^{34}$

The success of the protests, influenced by the release of information available to the CSOs, precipitated the federal government to announce a reduction in the new petrol price (from N141 to N97) and set up two committees to investigate claims of corruption in the sector. The Presidential Committee on Verification and Reconciliation of Subsidy Claims was set up to verify and reconcile the findings of the technical committee earlier instituted by the Federal Ministry of Finance to review all fuel subsidy claims and payments made in 2011. The committee, in its conclusion that N382 billion had been fraudulently paid under the subsidy scheme, made 22 recommendations that included the prosecution, recovery and punishments for external auditors and other government officials found culpable. ${ }^{35}$ The Petroleum Revenue Special Task Force was set up by the Minister of Petroleum in February 2012 to support the programme of the Federal Government of

33 "Occupy Nigeria: Civil Society, Labour Unions to Engage in Series of Mass Action in January 2012", Sahara Reporters (1 December 2011) <http:// saharareporters.com/2011/12/01/occupy-nigeria-civil-society-labour-unionsengage-series-mass-action-january-2012 > accessed 21 July 2015.

34 See the text of the press release by the group comprised of Action Aid, United Action for Democracy (UAD), Nigeria Labour Congress (NLC), Legislative Advocacy Centre (CISLAC) at "Occupy Nigeria: Civil Society, Labour Unions to Engage in Series of Mass Action in January 2012" Sahara Reporters (1 December 2011) <http://saharareporters.com/2011/12/01/occupy-nigeria-civil-societylabour-unions-engage-series-mass-action-january-2012> accessed 20 December 2015.

35 O. Adetayo, "Aig-Imoukhuede Committee indicts 21 Firms for Fraud" The Punch (25 July 2012) <www.punchng.com/business/business-economy/aigimoukhuede-committee-indicts-21-firms-of-fraud/> accessed 20 December 2015. 
Nigeria in enhancing optimisation, probity and accountability in the operations of the Petroleum Industry. ${ }^{36}$ The Task Force's report stated that the Nigerian National Petroleum Corporation (NNPC) and the Nigerian government have mismanaged the revenue accruing from oil and utilised it for illegal or nonapproved purposes with accountability or transparency. ${ }^{37}$ A House of Representatives investigation also concluded that the subsidy payments were shrouded in corruption with about US\$6.8bn lost between 2009 and 2011 through corruption, theft and mismanagement. ${ }^{38}$

These investigations were direct consequences of the protests by Occupy Nigeria precipitated by the information gathered by CSOs on the pervasive corruption in the oil industry. ${ }^{39}$ Without information to premise the opposition to the withdrawal of subsidy and the subsequent protests, any action in opposition to the said withdrawal would be baseless and lacking in merit. Thus, it is important not only to gather information but for such information to be verifiable. This means that it is not simply opposition statements but gathering of facts and figures that form hard evidence. The information were gathered over the years from different sources and pooled together to use for a common good.

Regarding the outcomes of the information gathering and use, it is clear that the government and its agencies were forced to investigate claims of corruption, one of the fundamental basis of opposition to the removal of subsidy. In fact, the final outcomes have not been great, since the perpetrators of the corrupt practices have not been apprehended. Specifically, while the House of Representatives recommended that the erring companies and their directors face criminal prosecution, the Attorney-General (AG) of Nigeria initially declined to prosecute the suspects. However, after pressure from the public and civil society, some of the suspects were arraigned in court. The charges were subsequently withdrawn by the state on the pretext "to enable the law enforcement agency conduct detailed investigations into the activities of the

36 Report of the Petroleum Revenue Special Task Force (2012). A copy of the report is available at the Sahara Reporters' website <http://saharareporters. com/sites/default/files/ribadu-report.pdf> accessed 20 December 2015.

37 ibid.

38 Patrick Smith, "Nigeria: The Great \$6.8bn Oil Scandal" Africa Report Magazine (Thursday, 19 July 2012). www.theafricareport.com/News-Analysis/indepthnigerias-great-68bn-oil-scandal.html accessed 20 December 2015.

39 Emmanuel and Ezeamalu (n 32). 
marketers, preparatory to preferring charges against them that can withstand legal scrutiny."40

With regards to the role of CSOs acting as watchdogs of the oil industry, a good example is its involvement in the Nigerian Extractive Industries Transparency Initiative (NEITI). Nigeria signed up to the EITI initiative in 2003 as part of the economic reforms under the Obasanjo administration. Thus, the NEITI have always engaged CSOs in its activities as a means of improving transparency and opening the process to the Nigerian public. This deliberate strategy of NEITI's involvement with NGOs can be traced to the onset of the EITI implementation or localisation in Nigeria, where a coalition of CSOs led by Publish What You Pay, through its various activities, sensitised the Nigerian public on the inherent benefits accruing from the implementation of the EITI to the extractive companies, government and the public. ${ }^{41}$ Furthermore, a host of other $\mathrm{CSOs}^{42}$ have been active in the EITI localisation by providing input and the NIETI board (management) have provided training and support to enhance the capacity of CSOs' effective participation in the NEITI in Nigeria. ${ }^{43}$

The EITI "is a global coalition of governments, companies and civil society working together to improve openness and accountable management of revenues from natural resources". ${ }^{44}$ The NEITI Act that aims to promote and ensure due process in the payments made by extractive companies to the coffers of the federal government of Nigeria ${ }^{45}$ is one of the few laws regulating

40 Iriekpen, D. "EFCC Suspends Arraignment of Marketers" ThisDay Newspaper (07 August 2012) www.thisdaylive.com/articles/subsidy-efcc-suspendsarraignment-of-marketers/121750/ accessed 20 December 2015.

41 Professor Asobie who is a former chairman of the NEITI board has argued that CSOs are an integral constituent of the EITI multi-stakeholder group (MSG), which comprises the government, private sector and civil society. See A. Asobie, "Foreword" in Civil Society in the NEITI Process" (2012) 6-7 <www.neiti.org.ng/ index.php?q=pages/civil-society-neiti-process $>20$ December 2015.

42 Some of CSOs participating in the NEITI include Africa Network for Environment and Economic Justice (ANEEJ), Civil Society Legislative Advocacy Centre (CISLAC) and Publish What You Pay Coalition (PWYP) amongst others. Generally, see Michael Uzoigwe, "Exploring Multi-Stakeholder Initiatives for Natural Resource Governance: The Example of the Nigerian Extractive Industries Transparency Initiative (NEITI)" (PhD Thesis, University of Birmingham 2012) 150.

43 Asobie (n 41).

44 See the EITI website at: http://eiti.org/eiti (accessed 20 December 2015).

45 Section 2 NEITI Act. 
Nigeria's oil and gas industry that expressly provides for the participation of CSOs in its activities. Section 6 provides that in making an appointment into the National Stakeholders Working Group (NSWG), the President shall include "(ii) representative of Civil Society". ${ }^{46}$

In addition to having a representative of CSOs on the board of the NEITINSWG, CSOs also constitute membership of the NEITI Civil Society Steering Committee with the NEITI Board that is responsible for various outreach initiatives and activities organised by the NEITI. ${ }^{47}$ Other roles assigned CSOs by the NEITI Act include remediation issues arising from NEITI audits, NEITILegislative engagement, dissemination of audit reports and community participation among others. ${ }^{48}$ In recognition of the important role that CSOs play in NEITI, a permanent (full time) Civil Society Liaison Officer is employed by the NEITI and a Memorandum of Understanding (MOU) was developed in 2006 to promote the CSO contribution to the NEITI. ${ }^{49}$ These include identification of issues (that ought to be of public interest to the fore), agenda setting, public education and enlightenment, agents of social change and mobilisation, monitoring and oversight, advisory, whistle blowing, observation and feedback. ${ }^{50}$

There are shortcomings in the practical involvement of CSOs in the NEITI process. ${ }^{51}$ Firstly, the lack of cohesion and consequent internal strife and division among CSOs, a situation exploited by the government, has dampened their expected levels of participation in the NEITI. ${ }^{52}$ Secondly, the appointment of CSO representative to the NEITI board is the prerogative of the President. Thus, the President may appoint a moderate personality that will not oppose government stance or activities. To redress this anomaly, the NEITI signed an MOU with CSOs that civil society will be consulted in selecting their representative. ${ }^{53}$ That notwithstanding, the prerogative to select the representative still rests (ultimately) with the President. This situation limits

46 Section 6 (2) (a) (ii) NEITI Act.

47 NEITI Handbook (2013) <www.neiti.org.ng/index.php?q=publications/neitihandbook $>$ accessed 20 December 2015.

48 Asobie (n 41).

49 CSO in NEITI Process (n 41) 10.

50 ibid 10, 24.

51 Nicholas Shaxson, Nigeria's Extractive Industries Transparency Initiative: Just a Glorious Audit (Chatham House 2009). < http://eiti.org/document/shaxsonneiti-glorious-audit> accessed 20 December 2015.

52 Musa Abutudu, \& Dauda Garuba, "Natural Resource Governance and EITI Implementation in Nigeria" (2011) 47 Current African Issues

53 Ekhator (n 27). 
the role that CSOs are expected to play as these groups ought to have the liberty to elect their representatives to the board. Electing a CSO representative to the NEITI board should (ideally) be based on merit, a manifesto or mandate that aligns with the broad aspirations of CSOs in line with current circumstances recognised and agreed to by CSOs. With the President appointing a CSO representative, they are no different from other government appointees on the board who serve at the will of the President.

Thirdly, it appears that the NEITI focuses on CSOs in Lagos and Abuja to the detriment of those that are active in the Niger Delta and are closer to the people most impacted by the oil industry. ${ }^{54}$ While one of the consequences of this omission is the absence of environmental matters from the remit of the NEITI Act, ${ }^{55}$ NEITI recently engaged in extensive nationwide consultations with NGOs. It is for reasons as this that it is better for a CSO representative to the NEITI Board to be left to civil society. Individuals interested in representing CSOs on the NEITI Board will have to outline a plan for their tenure on the board that would expectedly include the recognition of member organisations. Furthermore, electing a member to represent CSOs will promote a democratic process among themselves wherein all recognised organisations will have a vote and therefore be equal to others (irrespective of location and prestige/ visibility). Finally, there is the contention that the government and NEITI are more interested in gaining international credibility and legitimacy than actualising the mandate of the NEITI Act vis-à-vis CSO participation. ${ }^{56}$

To the extent that this contention may be valid, one may also point at the contributions that the CSOs have made to the NEITI process particularly and Nigeria's oil sector more generally, with satisfaction. While this is not suggesting that CSOs have made optimal contributions to the oil sector, and the NEITI process more particularly, it is clear that they have made a difference in the process of improving the accountability process in Nigeria's characteristically opaque oil industry. Decades of institutional rot in the management of Nigeria's oil industry requires years of consistent and painstaking involvement,

54 Eghosa Ekhator “The Roles of Civil Society Organisations in the Extractive Industries Transparency Initiative in Nigeria" (2014) 16(2) International Journal of Not-for-Profit Law 47-52.

55 N. Bassey, 'The Environmental Black Hole in NEITI' in Joab Peterside et al (eds), Domestication of Extractive Industries Transparency Initiative in Nigeria: Gaps between Commitment and Implementation - A Civil Society Assessment of the Performance of Nigeria Extractive Industries Transparency Initiative (Civil Society Legislative Advocacy Centre 2010.

56 Abutudu \& Musa (n 52) 196. 
monitoring and oversight as well as advocacy on the part of the CSOs to make considerable impacts. In effect, if it is the case that the "little" strides made by CSOs in the NEITI process are deemed nothing more than a smokescreen by the government, with time, the impacts of the CSOs may grow to become more substantive. Indeed, with the new government in place that has anti-corruption high on its agenda, this is the time for the CSOs to flourish within NEITI. ${ }^{57}$

It is trite to note that CSOs in Nigeria fulfilling their obligations as information gatherers do so without the advantage of a well-established freedom of information regime or the protection of whistle-blowers law. In Nigeria, as with many countries in Africa, the state partners with multinational corporations (MNCs) that operate the extractive industry, given that information on these operations are often considered sensitive and wellguarded. Justice Onalaja noted the difficulty in obtaining information in Nigeria's oil industry in Shell $v$. Isaiah thus:

A vital consideration in the oil spillage cases is the extent of the oil spillage. The pattern of defence of the appellant has been to withhold from the court the report of the oil spillage carried out by their employees. In Tiebo's case supra, the appellant's report of the oil spillage was similarly withheld from the court... ${ }^{58}$

Thus, CSOs often carry out independent investigations at their own costs and risk as well as making their findings easily accessible. ${ }^{59}$ This is a huge responsibility and a laudable one as the information gathered often forms the basis for further research and litigation and the attendant benefits. Nigeria's Freedom of Information (FoI) Act now provides a legal basis for CSOs to make legitimate requests for information that is not in the public domain. For example, following a decision by the ECOWAS Court of Justice on the right of the people and communities of the Niger Delta to a general satisfactory environment and to an adequate standard of living in SERAP $v$ Federal Republic of Nigeria, ${ }^{60}$ Amnesty International and Socio-Economic Rights and

57 Ekhator (n 28) 24.

58 Shell v Isaiah (1997) 6 NWLR (Pt. 508) 236.

59 Amnesty International "Nigeria: Petroleum, Pollution and Poverty in the Niger Delta" (2009) <www.amnesty.org/en/library/asset/AFR44/017/2009/en/ e2415061-da5c-44f8-a73c-a7a4766ee21d/afr440172009en.pdf $>$ accessed 20 December 2015.

60 The Court of Justice of the Economic Community of West African States (ECOWAS) holden at Ibadan, Nigeria, 14 Day of December 2012; General List No. ECW/CCJ/APP/08/09; Judgment No. ECW/CCJ/JUD/18/12. 
Accountability Project (SERAP) jointly sent a Freedom of Information request to the Federal Government of Nigeria to provide information on the measures taken to implement the court's decision. ${ }^{61}$

Although the implementation of the law is still far from perfect in Nigeria, the passage of the law opens new vistas of opportunity to promote transparency and accountability in Nigeria's oil industry. ${ }^{62} \mathrm{CSO}$ representatives noted that: "The signing of the FoI Bill into law is the clearest demonstration ever of the power of civil society working together to influence public policy and initiate reform" ${ }^{63}$ and "with the new law, Nigerians finally have vital tools to uncover facts, fight corruption and hold officials and institutions accountable." ${ }^{14}$ Also pertinent to note is that the passage of the law is indicative of what a vibrant CSO community can achieve despite the odds stacked against them. ${ }^{65}$ To put this in perspective, the FoI Act was signed into law (2011) after 11 years of its first submission to the National Assembly in 1999 and its passage by both the House of Representatives and the Senate in 2007. Perhaps even more intriguing is the fact that the bill was developed and submitted to the National Assembly by Freedom of Information Coalition, a network of over 150 civil society organisations in Nigeria, comprising civil rights, grassroots and communitybased non-governmental organisations led by the Media Rights Agenda. To

61 SERAP, "FOI: Amnesty International, SERAP task FG over implementation of ECOWAS oil pollution judgement" <http://serap-nigeria.org/foi-amnestyinternational-serap-task-fg-over-implementation-of-ecowas-oil-pollutionjudgment/> accessed 20 December 2015.

62 "Nigerian President Signs Freedom of Information Bill", Freedominfo.org (3 June 2011) <www.freedominfo.org/2011/06/nigerian-president-signs-freedom-ofinformation-bill/> accessed 20 December 2015.

63 Edetaen Ojo, Executive Director, Media Rights Agenda. See, "Nigerian President Signs Freedom of Information Bill" Freedominfo.org ( 3 June 2011) $<$ www.freedominfo.org/2011/06/nigerian-president-signs-freedom-ofinformation-bill/> accessed 20 December 2015.

64 Ene Enonche, Coordinator of the Right to Know initiative. See, "Nigerian President Signs Freedom of Information Bill" Freedominfo.org ( 3 June 2011) $<$ www.freedominfo.org/2011/06/nigerian-president-signs-freedom-ofinformation-bill/> accessed 20 December 2015.

65 A broad coalition of Nigerian CSOs worked and advocated for the passage of the FOI bill under the leadership of the Right to Know Movement, Nigeria, Media Rights Agenda, and the Open Society Justice Initiative in partnership with its sister organisation, the Open Society Initiative for West Africa. See, "Freedom of Information Act Signals Consolidation of Nigeria's Democracy", Press Release by Open Society Justice Initiative (May 31, 2011) <www.opensociety foundations.org/press-releases/freedom-information-act-signals-consolidationnigeria-s-democracy $>$ accessed 20 December 2015. 
consider that this coalition worked together for at least 11 years to achieve this feat is noteworthy of emulation, replication and consultation by African colleagues, especially in countries where such laws are still unheard of.

\subsection{Standard Setting}

CSOs in Nigeria have contributed to setting of standards in the oil industry, broadly speaking, in two ways. The first refers to the development of new laws and the other refers to their roles in development initiatives for the Niger Delta region. With regards their role in the development of new laws that create new standards, the analysis in the previous section attests to this assertion. Furthermore, CSOs have, and are, playing an integral role in the development of the Petroleum Industry Bill (PIB). The PIB is one of the most important bills in Nigeria's history. The plan is to develop it as the holistic legal and regulatory framework for the Nigeria's oil and gas industry.

Without going into the checkered history of the PIB that has remained stuck in the National Assembly since 2009, CSOs have played a vital part both in contributing to its development as a law and more pertinently, ensuring that the bill does not "die" in the legislature. Also, CSOs have made inputs to the bill by submitting memoranda to the National Assembly ${ }^{66}$ as well as honouring invitations by the National Assembly to make inputs to it. ${ }^{67}$ Regarding the role of CSOs to ensure that the bill does not go comatose in the legislature, Victoria Ohaeri, the Executive Director of the Spaces for Change (S4C), an NGO in Nigeria noted that the:

The [PIB] Bill was left to gather dust on the shelves of government offices after a major legislative effort to have the bill passed in 2009 was stalled. It was mainly the January 2012 protests (largely coordinated by civil society groups and NGOs) which forced major

66 Amnesty International Nigeria: Joint Memorandum on Petroleum Industry Bill, March 2012. Which was a coalition of Amnesty International and 12 Nigerian NGOs. Also see the Joint Position Paper on Petroleum Industry Bill: Issues of Concern to Communities and Civil Society. May 2011. Prepared by coalition of CSOs including the Civil Society Legislative Advocacy Centre (CISLAC) and Environmental Rights Action/Friends of the Earth, Nigeria amongst others. Available online at CISLAC website at <www.cislacnigeria.net/2011/07/policybrief-on-petroleum-industry-bill/> accessed 20 December 2015.

67 PIB Advocacy Working Group: Joint Civil Society Memorandum on the Petroleum Industry Bill (July 2013) < http://issuu.com/spaces.for.change/docs/ cso_joint_memorandum.july_17.2013> accessed 20 December 2015. 
high-level probes into the administration of fuel subsidies and reforms in the oil sector that awakened government interest in the PIB. ${ }^{68}$

In December 2015, the PIB was jettisoned and Petroleum Industry Governance and Institutional Framework Bill 2015 have replaced it. ${ }^{69}$

Murphy and Bendell in their definition of civil regulation highlight the importance of standard setting. According to them, civil regulation "is where organisations of civil society such as NGOs, set the standards for business behaviour. Enterprises then choose to adopt or not to adopt those standards." ${ }^{70}$ The involvement of CSOs in community development initiatives and activities in the Niger Delta is appreciated against the backdrop of community development carried out by the state and MNCs operating in the region. Indeed the literature is replete with the argument that the lack of development of the Niger Delta is a fundamental factor that feeds the cycle of poverty and violence in the region. ${ }^{71}$ While visits to the region confirm the varied assertions, the Akassa community stood out for its unique development structure and achievements since the mid-1990s, a period when the region was becoming restive due to the perceived "underdevelopment". The next section focuses on the Akassa initiative.

\subsection{Collaboration between CSOs and Oil MNCs in Nigeria's Extractive Sector}

This section contends that CSOs in Nigeria have gone from passive bystanders to active collaborators in the extractive industry. The Akassa community is an example of a successful collaborative effort between MNC and oil producing community in developing CSR projects or standards. Statoil selected the Akassa community in Bayelsa State for a social initiative after Environmental Impact

68 Culled from a Facebook conversation with Victoria Ohaeri (Executive Director, Spaces for Change) on May 21, 2013. A copy of the conversation is available on file with authors.

69 Julia Payne "Exclusive: Stalled Nigerian oil broken up, new draft splits state giant" Reuters (7 December 2015) <www.reuters.com/article/us-nigeria-oillawmaking-idUSKBNOTQ27R20151207>

70 David Murphy \& Jem Bendell, "Editorial" (1998) Winter Greener Management International 8 cited in Neil Gunningham, "Environmental Law, Regulation and Governance: Shifting Architectures" (2009) 21 (2) Journal of Environmental Law 179.

71 Cyril Obi, "Nigeria's Niger Delta: Understanding the complex drivers of violent oil-related conflict" 34 (2) (2009) African Development 103. 
Assessment (EIA) studies identified the community as most likely to be impacted by the company's deep-water offshore wells. ${ }^{72}$

The company adopted a unique method of CSR delivery in Nigeria by partnering with a non-governmental charitable organisation - Pro Natura (International) - to initiate and facilitate the community development projects based on a "participatory development model" ${ }^{73}$ With the company providing the funds, Pro Natura set to advance a development model with the active participation of all sections of the community. The resultant Akassa Community Development Programme (ACDP) established in 1998 was easily regarded and recognised as "owned" by the community. The ACDP concentrated on building new local institutions to initiate and manage activities in the fields of poverty alleviation, health, education, natural resources and works. In 2002, it evolved to the Akassa Development Foundation (ADF), a legally incorporated trust with capacity to enter into contracts on behalf of the people of Akassa and bear legal responsibility for the contracts. It also has a bank account of its own, a well thought out constitution and a board of trustees elected by the Akassa people. ${ }^{74}$ It is unsurprising that even when the rest of the Niger Delta was enmeshed in violent conflicts, the Akassa community remained peaceful with the community development initiative playing a major role.

More pertinent to the discussion in this section of the paper is that the initiative has set a standard in community development programmes in the region. Thus, the Akassa model in the Niger Delta is an example wherein standards were set by the CSO (Pro Natura, a Nigerian CSO) (with the active participation of the Akassa community) in partnership with the oil MNC. Many of the oil MNCs operating in the Niger Delta have since repackaged their community assistance projects, significantly partnering with CSOs to conceptualise and deliver on them. For example, Chevron has endowed the Niger Delta Partnership Initiative (NDPI) Foundation with US\$50 million over a five-year period from 2010 to 2014 with the latter aiming to raise the

72 Norwegian Embassy Nigeria Website “CSR: Statoil's Akassa Community Development Project" <www.emb-norway.com.ng/Norsk/Naringsliv-ognaringslivssamarbeid1/CSR-Statoils-Akassa-Community-DevelopmentProject1/> accessed 20 December 2015.

73 ibid.

74 ibid. 
portfolio to US\$100 million with donor partner funding. ${ }^{75}$ The Initiative's Nigerian affiliate, the Foundation for Partnership Initiatives in the Niger Delta (PIND), will participate in the design, development and monitoring of programmes. PIND's remit includes the economic development, capacity building, peace building, as well as analysis and advocacy. Interestingly, communities, including five local council areas in the Oron region of Bayelsa State, have also adopted the Akassa model to promote their development. ${ }^{76}$

\subsection{Behaviour Modification}

Behaviour modification is perhaps the most potent of the strategies that CSOs in Nigeria have utilised to influence changes in the legal framework regulating the extractive industry. Simply, it refers to the avenues that CSOs exploit to galvanise public opinion in raising awareness and/or support for a cause. ${ }^{77}$

CSOs in Nigeria rely extensively on organised protests, litigation, publications, lobbying of the MNCs and the State, public awareness campaigns to effect behaviour modification vis-à-vis the oil industry. ${ }^{78} \mathrm{CSO}$ in Nigeria have a long history of protesting the activities of the oil industry with the earlier periods characterised by uncoordinated efforts of loosely formed groups such as traditional elders and elite members of the region, for example. The activities of MOSOP in the 1990s changed things radically because the group was able to mobilise the Ogonis (an entire ethnic group) to identify with and support its cause. ${ }^{79}$ Furthermore, due to the impact of Shell's activities on Ogoniland and its alleged collusion with Nigerian authorities in the trial and "murder" of Ken Saro-Wiwa (who was one of the leaders of Ogoniland),

75 Catherine Keller "Business as a Community Transformation Partner: Chevron and the Niger Delta Partnership Initiative" U.S. Chamber of Commerce Foundation (23 February 2012) <www.uschamberfoundation.org/blog/post/ business-community-transformation-partner-chevron-and-niger-deltapartnership-initiative $>$ accessed 20 December 2015.

76 Rhuks Ako, "The Struggle for resource control and violence in the Niger Delta" in Cyril Obi and Siri Rustad (eds.) Oil and Insurgency in the Niger Delta (Zed Books 2011).

77 John Braithwaite and Peter Drahos, Global Business Regulation (Cambridge University Press 2000).

78 Oshionebo (n 16).

79 Rhuks Ako "A Lega(1)cy Unfulfilled: Reflections of the Wiwa-Led MOSOP and the Localisation of Human Rights" (2015) 2 (4) Extractive Industries and Society 625. 
MOSOP and the people of Ogoniland rejected Shell and withdrew its "social licence" by protesting and mobilising against Shell. ${ }^{80}$

Thus, for more than twenty years, Shell has not operated any of its facilities in Ogoniland. ${ }^{81}$ Ogoniland community "revoked" the social licence of Shell to operate in its area notwithstanding that under Nigerian laws, Shell has the right to operate in the region. While other ethnic groups in the region borrowed the MOSOP-template to organise their protests, the Federal Government's highhanded responses contributed to the rise of militancy as a means of further protests. Notably, women have also led protests in the Niger Delta with the Ugborodo protests of 2002 resulting in Chevron/Texaco's declaration of a force majeure and the company signing an MOU with the community. ${ }^{82}$

Litigation has now become a deliberate strategy employed by CSOs in their bid to influence the activities of the state and oil companies that operate the oil industry in Nigeria. The rising number of cases instituted both in Nigeria and abroad by, or, with the assistance of CSOs is an indication of the rising reliance on litigation. These cases have been instituted across court systems and jurisdictions around the globe. For instance, while Gbemre $v$. $S P D C$ was initiated in a Federal High Court in Nigeria; Bowoto $v$. Chevron and Wiwa $v$. Shell were instituted in the USA; Akpan $v$. Shell was heard at The Hague, Netherlands while Bodo Community $v S P D C^{83}$ was heard in the

80 Ekhator (n 28). Neil Gunningham, et al "Social Licence and Environmental Protection: Why Businesses Go Beyond Compliance” (2004) 29(2) Law \& Social Enquiry 307-341, 308 defined social licence as "the demands on and expectations for a business enterprise that emerge from neighbourhoods, environmental groups, community members and other elements of the surrounding civil society." Thus, an MNC with a social licence is deemed to be legitimate and accountable to the government and other stakeholders in the society.

81 M Eboh, "Shell begins pull-out from Ogoniland" Vanguard (10 April 2013) <www.vanguardngr.com/2013/04/shell-begins-pull-out-from-ogoni-land/> accessed 20 December 2014. However, a subsidiary of the Nigerian National Petroleum Corporation (NNPC), the Nigerian Petroleum Development Company (NPDC) has indicated that it is willing to take over Shell's oil wells in Ogoniland. The people of Ogoniland are against this move contending that Federal Government and Shell has refused to implement the UNEP report on Ogoniland, which was highly critical of Shell. See C Amanze-Nwachukwu, "Shell Oil Fields: Ogonis resist NPDC's re-entry moves" ThisDay Newspaper (19 February 2013) $<$ www.thisdaylive.com/articles/shell-oil-fields-ogonis-resist-npdc-s-re-entrymoves/139952/> accessed 20 December 2015.

82 Charles Ukeje, "From Aba to Ugborodo: Gender Identity and Alternative Discourse of Social Protest among Women in the Oil Delta of Nigeria" (2004) 32 (2) Oxford Development Studies 605.

83 [2014] EWHC 1973 (TCC). 
United Kingdom. In addition to national jurisdictions, regional judicial bodies including the ECOWAS Court ${ }^{84}$ and the African Commission on Human and People's Rights ${ }^{85}$ have also heard cases or communications. Although litigation has yielded a mixed bag of results, there have been some notable gains, even in situations where the victories have been regarded as pyrrhic. ${ }^{86}$ Specifically, in Wiwa v. Shell, the high profile nature of the case put Shell and its subsidiaries in the spotlight; further propelled the situation in the Niger Delta into international reckoning and resulted in financial settlements that the company would otherwise not have agreed to pay.

Other cases have had more direct effects on behaviour modification. For instance, the activities of CSOs working on the Gbemre case - Rights Action/ Friends of the Earth and Climate Justice Programme (CJP) - had two significant impacts on the Iwherekan community. First, the community became aware of the negative impacts of gas flaring on their environment and lives. Second, they were able to, with the support of the CSOs, initiate legal proceedings to challenge the continued flaring of gas in their community. Although the decision of the court that mandated the Federal Government to review some relevant laws is still under appeal, the Senate's passage of the Gas Flaring Prohibition and Punishment Bill of 2009 is purportedly a direct impact of the case.$^{87}$ Notably, it can be argued that there is no direct correlation between CSO activities and change in attitude of oil companies directly linked to this law. Observably, the case has contributed to the jurisprudence on oilrelated litigation in Nigeria and appears to have highlighted the significant impact that litigation may have on effecting the required change in Nigeria's oil industry. ${ }^{88}$

84 SERAP v Federal Republic of Nigeria, Judgment No ECW/CCJ/JUD/18/12.

85 Social and Economic Rights Action Centre (SERAC) and the Centre for Economic and Social Rights (CESR) v. Nigeria.

86 Engobo Emeseh and Rhuks Ako, "The Wiwa v Shell Settlement: Victory for Corporate Accountability for Environmental and Human Rights Abuses?" SLSA Conference (University of West England, Bristol, UK, April 1 2010).

87 Funmi Abioye, "The rule of law in English speaking African countries: the case of Nigeria and South Africa" (PhD Thesis, University of Pretoria, South Africa 2011) 240.

88 Godwin Ojo, "Against the Expansion of the Oil Frontier: Historicising Civil Society Initiatives to Leave Oil in the Soil in Nigeria" in Leah Temper et al, Towards a Post-Oil Civilisation: Yasunisation and other initiatives to leave fossil fuels in the soil (EJOLT Report 2013 No. 6) 41-43 <www.ejolt.org/2013/05/towards-a-postoil-civilisation-yasunisation-and-other-initiatives-to-leave-fossil-fuels-in-the-soil/ > accessed 20 December 2015. 


\section{CONCLUSION}

Civil society works in tandem with democratic values. Imade argues that in the Nigerian context: a weak civil society and non-democratic culture is to a large degree the product of political instability: conversely a vibrant civil society coupled with civility and social capital are the basic building blocks for democratic survival. ${ }^{89}$ Moreover, a vibrant civil society can champion government reforms, confront corruption, advocate respect for human rights, promote and defend democratic processes and institutions. Imade further posited that giving civil society a greater role in governance is the most effective avenue to economic development, sustainable peace and stable government in Nigeria.

In Nigeria, CSOs perform regulatory functions via their activities in the oil and gas sector, particularly pertaining to MNCs. For example, CSOs can challenge MNCs through boycott, public campaigns and other forms of pressure. According to Oshionebo, ${ }^{90}$ this is akin to the impact of state regulation and misdemeanours of such MNCs can lead to social sanctions. In addition, CSOs are independent of the MNCs and the Nigerian State. Thus, they are in a position to advice and influence both the MNCs and the state without bias. Furthermore, CSOs can also influence regulation through litigation, publications, lobbying of the MNCs and the State, public awareness campaigns, among other strategies. ${ }^{91}$ CSOs have been very proactive in litigation, especially in areas of oil pollution, environmental degradation and human rights. Such litigations have added to a growing jurisprudence on regulation of MNCs by CSOs in Nigeria. ${ }^{92}$ This is evident in human rights protection within Nigeria where the courts have produced "pro-human rights alterations and reformations." 93 Thus, the Nigerian government has "become more sensitive to the environmental and social responsibilities of oil companies"94 and MNCs are expected to "negotiate and reach memoranda of understanding with host communities, honour agreements, and be more responsive to [their] problems." ${ }^{95}$

89 Lucky Imade, "Democratising Democracy in Nigeria: The Role of Civil Society Organisations" (2001) 3(1) Journal of Sustainable Development in Africa 8.

90 Oshionebo (n 16).

91 ibid.

92 Eghosa Ekhator, "Improving Access to Environmental Justice under the African Charter: The Roles of NGOS in Nigeria" (2014) 22(1) African Journal of International and Comparative Law 63.

93 Obiora Okafor, "Modest Harvests: On the Significant (but Limited) Impact of Human Rights NGOs on Legislative and Executive Behaviour in Nigeria" (2004) 48(1) Journal of African Law 23, 24.

94 ibid.

95 Ikelegbe (n 18) 460. 